
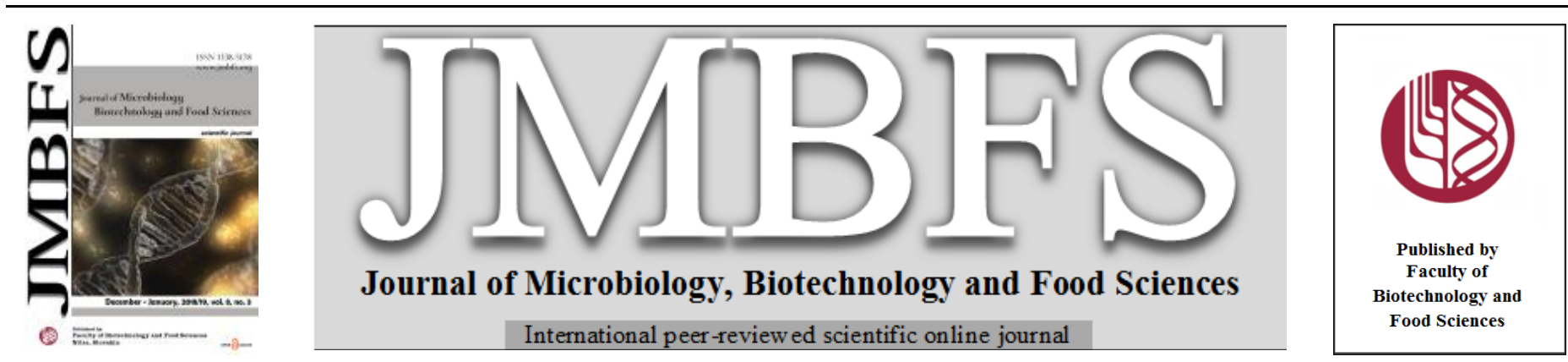

\title{
INHIBITION EFFECTS OF SOME ANTIMICROBIAL AGENTS FROM SALVIA OFFICINALIS L. ON THE GROWTH OF SELECTED GRAM-NEGATIVE AND GRAM-POSITIVE BACTERIAL STRAINS
}

\author{
Miroslava Císarová *l, Eva Ürgeovál, Lukášs Hleba², Ivana Charousováa ${ }^{3}$ Matěj Božik ${ }^{4}$, Pavel Klouček ${ }^{4}$, Tibor Maliar ${ }^{l}$
}

$\operatorname{Address}(e s)$ :

${ }^{1}$ University of SS. Cyril and Methodius, Department of Biology, Faculty of Natural Sciences, Nám. J. Herdu 2, SK-91701 Trnava, Slovak Republic.

${ }^{2}$ Slovak University of Agriculture in Nitra, Department of Microbiology, Faculty of Biotechnology and Food Sciences, Tr. A. Hlinku 2, 94976 , Nitra, Slovak Republic. ${ }^{3}$ Clinical Microbiology Laboratory, Alpha medical s.r.o., J. Bellu 66, 03495 Likavka, Slovak Republic.

${ }^{4}$ Czech University of Life Sciences, Faculty of Agrobiology, Food and Natural Resources, Department of Quality of Agricultural Products, Kamýcka 129, 16521

Prague, Czech Republic.

*Corresponding author: miroslava.cisarova@ucm.sk, miroslava.cisarova@gmail.com

doi: $10.15414 / j m b f s .2018-19.8 .3 .960-964$

\section{ARTICLE INFO}

Received 9. 8. 2018

Revised 11.9. 2018

Accepted 25. 10. 2018

Published 1. 12. 2018

Regular article open $\bigodot_{\text {ACCESS }}$

\begin{abstract}
In the present study, the antimicrobial activity of sage oil, some of its pure components (1,8-cineole, borneol and a- $\beta$ thujone) and sage extract were investigated against selected strains of Gram-positive bacteria (Enterococcus faecalis, Staphylococcus aureus) and Gramnegative bacteria (Klebsiella pneumoniae, Escherichia coli). The antimicrobial activities of the used antimicrobials agents were determined by using the micro broth dilution method according to Clinical and Laboratory Standards Institute. The percentage of bacterial growth was determined by measured absorbance on a Microplate Reader Opsys MRTM, Dynex (Chantilly, USA). The best minimum inhibitory concentration (MIC) was found against Gram-positive bacteria S. aureus CCM 4223 by sage essential oil with $\mathrm{MIC}_{50} 96.05 \mu \mathrm{g} / \mathrm{mL}$. The results from the percentage growth of tested bacteria showed that antimicrobial agents inhibit more Grampositive, than Gram-negative bacterial strains.

The chemical composition of sage essential oil (EO) was analysed using the gas chromatography-mass spectrometry (GC-MS). Sage EO contains primarily a -thujone $(14.00 \%)$, borneol $(12.90 \%)$, camphor $(12.90 \%)$, (-)-Isopulegol $(10.10 \%)$, B-thujone $(8.40 \%)$ and 1,8 cineole $(8.00 \%)$. The antioxidant properties of sage oil $(71.55 \%)$ and sage propylene glycol extract $(60.93 \%)$ were measured by testing their scavenging effect on DPPH radical activities. Due to antibacterial activity of the tested antimicrobials from sage, the problem of microbial resistance to conventional antibiotics could be treated by pharmaceutical industries to manufacture antibacterial drugs.
\end{abstract}

Keywords: essential oils, extract, antimicrobial activity, Gram-positive and Gram-negative bacteria

\section{INTRODUCTION}

Antibiotics are probably the most used drugs in human medicine, and over the last few years, abuse in the use of these drugs has created multidrug resistance (MDR), what puts the effective treatment of a growing number of infections caused by pathogenic microorganisms at serious risk (Barreto et al., 2014). The battle between antimicrobial-resistant pathogens and antibiotic therapy is an evolutionary arms race-one that we are currently losing. Consequently, antimicrobial resistance (AMR) - related deaths have reached alarming rates throughout the world. Estimates suggest that at least 700,000 people die annually from drug-resistance infections; this number could rise to 10 million by 2050 , far surpassing cancer as the major cause of death worldwide (O'Neill, 2014). Nosocomial infections are an important factor in the emergence and spread of multidrug-resistant (MDR) bacteria. Broadspectrum antibiotics, such as vancomycin, third-generation cephalosporins and carbapenems, are often used for empirical treatment of infected patients, thereby selecting for and favouring the persistence of MDR pathogens (Jenkins, 2017). The most critical group of all includes multidrug resistant bacteria that pose a particular threat in hospitals, nursing homes, and among patients whose care requires such devices as ventilators and blood catheters. They include Acinetobacter, Pseudomonas and various Enterobacteriaceae (including Enterbacter spp., Klebsiella pneumoniae, E. coli, Serratia, and Proteus) (WHO, 2017). The highest ranked Gram-positive bacteria (high priority) were vancomycin-resistant Enterococcus faecium, Enterococcus faecalis and meticillin-resistant Staphylococcus aureus (Tacconelli et al., 2018). Most efforts to resolve AMR are geared toward the development of novel antibiotics, yet resistance has arisen to every antibiotic used in the clinic. Innovative strategies to reduce the rise of drug-resistant pathogens are therefore a necessary public health concern (Ragheb et al., 2018). This situation requires some effort to help combat such problems. One possible solution is to search for alternative therapies to control these diseases. An alternative is the use of essential oils to achieve control over antibiotic-resistant microorganisms (Veras et al., 2012; Raut and Karuppayil, 2014). In fact, many studies of essential oils have been carried to develop bio-products and safer drugs of industrial interest
(Hsouna et al., 2011). Undeniably, the technological application of a specific essential oil must be supported by scientific researches in order to prove its effectiveness as antimicrobial agent and to elucidate health outcomes linked with its future uses (Lahmar et al., 2016).

In this investigation, we aimed to determine the antimicrobial activity of Sage oil some of its pure components (1,8-cineole, borneol and $a-\beta$ thujone) and sage extract against selected strains of Gram-positive bacteria (Enterococcus faecalis, Staphylococcus aureus) and strains of Gram-negative bacteria (Klebsiella pneumoniae, Escherichia coli).

\section{MATERIAL AND METHODS}

\section{Antimicrobial samples}

The essential oil of Salvia officinalis L. and propylene glycol extract of Salvia officinalis L. (leaf) used in this study were supplied by Calendula company a.s. (Nová Lubovňa, 238 A, Slovakia). The phenolic compounds standards, concretely: 1,8-cineole, borneol and $\mathrm{a}-\beta$ thujone were of analytical grade purity and were obtained from Merck (Germany). Sage essential oil and extract were stored in air-tight sealed glass bottles at $4{ }^{\circ} \mathrm{C}$; used standards were stored at $4{ }^{\circ} \mathrm{C}$ until the analysis.

\section{GC-MS analysis of Sage essential oil}

Essential oils constituents were identified and the relative composition of the oil was determined by gas chromatography followed by mass spectrometry (GCMS) as described by Císarová et al. (2018). The identification of constituents was performed by matching their mass spectra and retention indices with those obtained from authentic samples and/or NIST/Wiley spectra libraries and available literature data (Adams, 2007). Relative proportions were calculated by dividing individual peak area by total area of all peaks. Only compounds over $1 \%$ were included. 


\section{Free radical scavenging assays}

The antioxidant activity of sage essential oil and propylene glycol extract was determined by the radical 2,2-Diphenyl-1-picrylhydrazyl (DPPH, Sigma-Aldrich, German). Determination of the antioxidant activity by the DPPH method (scavenging of DPPH radical) in vitro was carried out by the method of Hatano et al. (1988) with modification for microplate form. Fifty $\mu \mathrm{L}$ of tested samples were added into $100 \mu \mathrm{L}$ of DPPH solution $(0.012 \mathrm{~g}$ of DPPH dissolved in $100 \mathrm{~mL}$ of ethanol, $96 \%, \mathrm{v} / \mathrm{v})$. The obtained solutions were shaken and left for incubation (30 min) at darkness at room temperature for any reaction to occur. Absorbance was recorded at $517 \mathrm{~nm}$ using Microplate Reader Opsys MRTM, Dynex (Chantilly, USA). Antioxidant activity was expressed as percentage (\%) of scavenging activity:

\section{DPPH scavenging activity $(\%)=\left[\left(\mathrm{A}_{0}-\mathrm{A}_{1}\right) * 100\right] / \mathrm{A}_{0}$}

where $A_{0}$ is the absorbance of the blank sample and $A_{1}$ is the absorbance of the test sample at $30 \mathrm{~min}$. The sample concentration providing $50 \%$ inhibition $\left(\mathrm{IC}_{50}\right)$ was calculated by plotting inhibition percentages against concentrations of the sample. The analyses were performed in triplicate.

\section{Bacterial strains}

To determine the antibacterial effects of Sage EO, sage extract and phenolic compounds, four kinds of bacteria were used in this study such as Gram-negative strains: Escherichia coli CCM 3954, Klebsiella pneumoniae CCM 2318 and Enterobacter faecalis CMM 4224, and Gram-positive strains: Staphylococcus aureus CCM 4223. The test strains were incubated in the Muller-Hinton broth medium (Hi-Medium, India) (MHB) at $37{ }^{\circ} \mathrm{C}$ for $16 \mathrm{~h}$ to obtain the active cultures.

\section{Inoculum preparation}

Overnight bacterial cultures were transferred to MHB and the suspension was adjusted to $0.5 \mathrm{McF}$ arland standards. The suspension was subsequently diluted in cultivation medium to get the final concentration of $5 \times 10^{5} \mathrm{CFU} / \mathrm{mL}$ in the inoculated broth that was confirmed by colony count performed according to the CLSI guidelines (CLSI, 2009). The same inoculum preparation procedure was used for all experiments carried out in this study.

\section{Determination of minimum inhibitory concentration}

Determination of MIC (minimum inhibitory concentrations) was performed by serial microdilution technique using 96-well microtiter plates containing MuellerHinton broth. Briefly, the sage essential oil, 1,8-cineole and a- $\beta$ thujone were diluted in MHB with the addition of Tween 80 content $0.5 \%$. Borneol was dissolved in dimethyl sulphoxide (DMSO) and following diluted in MHB where maximum DMSO content was $1 \%$. Propylene glycol extract of Salvia officinalis L. was diluted directly in MHB until analysis. All used antimicrobials were prepared to give initial concentration of $512 \mu \mathrm{g} / \mathrm{mL}$. The two-fold serially diluted concentrations of all antimicrobials ranging from 512 to $0.25 \mu \mathrm{g} / \mathrm{mL}$. Final bacterial concentration was prepared as $0.5^{\circ} \mathrm{McF}$. In this test, the wells in the last column in all plates used for all tested strains were used as a positive control for optical density measurement (6 wells) and as sterility control of MHB (6 wells). The microplates were incubated at $37{ }^{\circ} \mathrm{C}$ during $24 \mathrm{~h}$. The lowest concentration of the antimicrobial which prevents the growth of the bacterial was defined as the minimal inhibitory concentrations (MIC). The optical density was measured on a Microplate Reader Opsys MRTM, Dynex (Chantilly, USA) at $405 \mathrm{~nm}$. The 96well microtiter plates were measured before and after $(24 \mathrm{~h}$.) experiment. The results were expressed as a mean of three replicates in three independent tests.

\section{Statistical analysis}

The statistical analysis was performed by Probit analysis by using statistical program Statgraphic (Statpoint technologies, Warrenton, VA, USA) according to Hleba et al. 2014 with some modifications.

\section{RESULTS AND DISCUSSION}

Sage (Salvia officinalis L.), which is one of the most important pharmaceutical herbs, has been exploited for many uses (Vosoughi et al., 2018). EO from the sage is already known to present antimicrobial action against various bacteria and fungi (Mandras et al., 2016; Shahbazi et al., 2015; Snoussi et al., 2015). According to the results of phytochemical analysis of Salvia species oils, the main constituents of the oils are monoterpenes ( $\alpha$-and $\beta$-thujone, 1,8-cineole camphor, and linalool), sesquiterpenes ( $\alpha$-humulene), and phenolics (Roby $\boldsymbol{e t}$ al. 2013; Martins et al., 2015). For borneol and 1,8-cineole have been reported antimicrobial activities. The antimicrobial activity of both $\alpha$ - and $\beta$-thujones was also confirmed (Tsiri et al., 2009; Rashid et al., 2013) and a synergistic interaction was observed when the two isomers were tested in a mixture (Viljoen et al., 2006). In this research we tested sage EO, sage extract and some phenolic compounds present in sage. The minimum inhibitory concentration (MIC) $\mathrm{MIC}_{50}$ and $\mathrm{MIC}_{90}$ (expressed as $\mu \mathrm{g} / \mathrm{mL}$ ) of five antimicrobials against four strains of bacteria are summarized in Table 1.

Table 1 The minimum inhibitory concentration (MIC) of tested antimicrobials expressed as $\mu \mathrm{g} / \mathrm{mL}$

\begin{tabular}{|c|c|c|c|c|c|c|c|c|}
\hline \multirow{3}{*}{ Tested antimicrobials } & \multicolumn{4}{|c|}{ Gram-negative } & \multicolumn{4}{|c|}{ Gram-positive } \\
\hline & \multicolumn{2}{|c|}{ E. coli } & \multicolumn{2}{|c|}{ K. pneumoniae } & \multicolumn{2}{|c|}{ E. faecalis } & \multicolumn{2}{|c|}{ S. aureus } \\
\hline & MIC 50 & MIC 90 & MIC 50 & MIC 90 & MIC 50 & MIC 90 & MIC 50 & MIC 90 \\
\hline \multirow{3}{*}{$\alpha-\beta$ thujone } & \multicolumn{2}{|c|}{$p$ Value } & \multicolumn{2}{|c|}{$p$ Value } & \multicolumn{2}{|c|}{$p$ Value } & \multicolumn{2}{|c|}{$p$ Value } \\
\hline & $>512$ & $>512$ & $>512$ & $>512$ & $>512$ & $>512$ & $>512$ & $>512$ \\
\hline & \multicolumn{2}{|c|}{ nd } & \multicolumn{2}{|c|}{ nd } & \multicolumn{2}{|c|}{ nd } & \multicolumn{2}{|c|}{$n d$} \\
\hline \multirow{2}{*}{ 1,8-cineole } & $>512$ & $>512$ & 383.00 & 407.13 & 383.00 & 407.13 & $>512$ & $>512$ \\
\hline & \multicolumn{2}{|c|}{$n d$} & \multicolumn{2}{|c|}{0.0002} & \multicolumn{2}{|c|}{0.0002} & \multicolumn{2}{|c|}{ nd } \\
\hline \multirow{2}{*}{ Borneol } & $>512$ & $>512$ & 553.48 & 928.02 & 451.94 & 890.42 & 2726.25 & 6219.10 \\
\hline & \multicolumn{2}{|c|}{$n d$} & \multicolumn{2}{|c|}{0.1179} & \multicolumn{2}{|c|}{0.1261} & \multicolumn{2}{|c|}{0.8657} \\
\hline \multirow{2}{*}{ Salvia extract } & 773.24 & 1662.83 & 553.48 & 928.02 & 503.07 & 1270.30 & 1385.70 & 2574.31 \\
\hline & \multicolumn{2}{|c|}{0.4613} & \multicolumn{2}{|c|}{0.1179} & \multicolumn{2}{|c|}{0.3596} & \multicolumn{2}{|c|}{0.6606} \\
\hline \multirow{2}{*}{ Salvia EO } & 191.83 & 203.97 & 383.00 & 407.13 & $>512$ & $>512$ & 96.05 & 102.31 \\
\hline & \multicolumn{2}{|c|}{0.0001} & \multicolumn{2}{|c|}{0.0002} & \multicolumn{2}{|c|}{$n d$} & \multicolumn{2}{|c|}{0.0001} \\
\hline
\end{tabular}

We did not detect any antimicrobial effect of $\alpha-\beta$ thujone in this study (MIC $\mathrm{M}_{50}$ and $\mathrm{MIC}_{90}$ >512). All tested strains were resistant to $\alpha-\beta$ thujone. The strains $E$. faecalis CCM 4224 were found to be more susceptible to the borneol with a $\mathrm{MIC}_{50}$ value of $451.94 \mu \mathrm{g} / \mathrm{mL}$ and $K$. pneumoniae CCM 2318 with $\mathrm{MIC}_{50}$ value of $553.48 \mu \mathrm{g} / \mathrm{mL}$. Both strains were sensitive to 1,8 -cineole with the same $\mathrm{MIC}_{50}$ value of $383.00 \mu \mathrm{g} / \mathrm{mL}$. S. aureus CCM 4223 with higher $\mathrm{MIC}_{50}$ values $(2726.25 \mu \mathrm{g} / \mathrm{mL})$ was found the least sensitive to borneol. But this strain was found to be most sensitive to salvia EO ( MIC $_{50} 96.05 \mu \mathrm{g} / \mathrm{mL}$ ), followed by $>E$. coli CCM $3954(191.83 \mu \mathrm{g} / \mathrm{mL})>$ K. pneumoniae CCM $2318(383.00 \mu \mathrm{g} / \mathrm{mL})$. Vetas et al. (2017) tested antibacterial activity of sage and spearmint essential oils against $S$. aureus. The results showed that both EOs presented MIC and MBC equal to 1.25 and $2.5 \%$, respectively. E. faecalis CCM 4224 was resistant to salvia EO, in this study. 1,8-cineole had no antimicrobial effect on strains $E$. coli CCM 3954 and $S$. aureus CCM 4223. The best antimicrobial effect of tested salvia extract was shoved against strain E. faecalis $\mathrm{CCM} 4224$ with $\mathrm{MIC}_{50}$ value $503.07 \mu \mathrm{g} / \mathrm{mL}$, followed by $K$. pneumoniae CCM $2318(553.48 \mu \mathrm{g} / \mathrm{mL})>$ E. coli CCM $3954(773.24 \mu \mathrm{g} / \mathrm{mL})$ and S. aureus CCM $4223(1385.70 \mu \mathrm{g} / \mathrm{mL})$. In our study, the Gram-negative bacterial strains were more sensitive to 1,8-cineole than
Gram-positive tested strains. In study of Bosnić et al. (2006), the tested compound 1,8-cineole seems to be more effective against Gram-positive strains (S. aureus and B. subtillis). They found no effect of this compound against Gramnegative strains (E. coli and P. aeruginosa).

Based on the measured absorbance on a Microplate Reader Opsys MRTM, Dynex (Chantilly, USA), we determined the percentage of bacterial growth. We established $100 \%$ bacterial growth in pure MHB and this value was compared against bacterial growth under treatments with antimicrobial agents, statistically. The results showed that antimicrobial agents inhibit more Gram-positive, than Gram-negative bacterial strains. The growth of E. faecalis CCM 4224 and S aureus CCM 4223 was inhibited by all tested antimicrobials in comparison with control sets. The growth of E. faecalis (Fig. 1) was inhibited by sage extract and by borneol at concentration $128 \mu \mathrm{g} / \mathrm{mL}$ completely. The least inhibitory effect on the growth of this species was observed in treatment with $\alpha-\beta$ thujone, followed by sage EO. S. aureus (Fig. 2) was inhibited completely only by sage EO at concentration $128 \mu \mathrm{g} / \mathrm{mL}$. Also, the least inhibitory effect for this strain was determined in a treatment with $\alpha-\beta$ thujone. 
Enterococcus faecalis CCM 4224

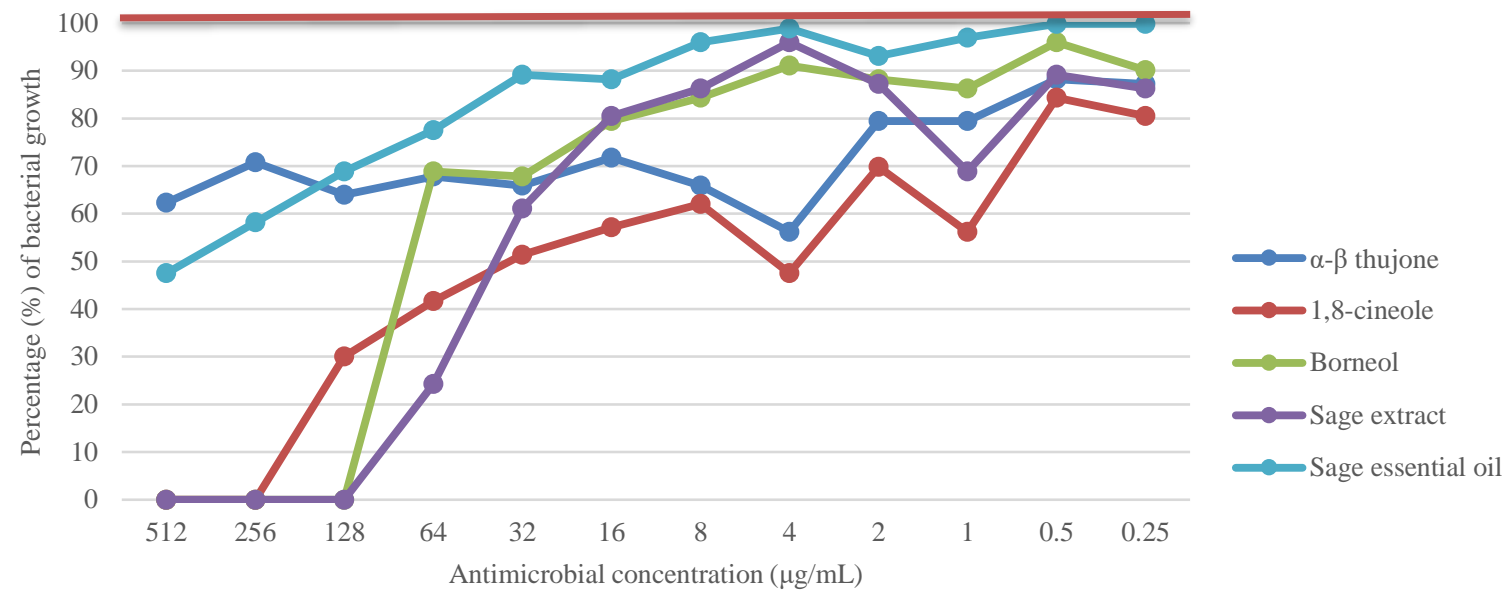

Figure 1 The percentage (\%) growth of E. faecalis CCM 4224

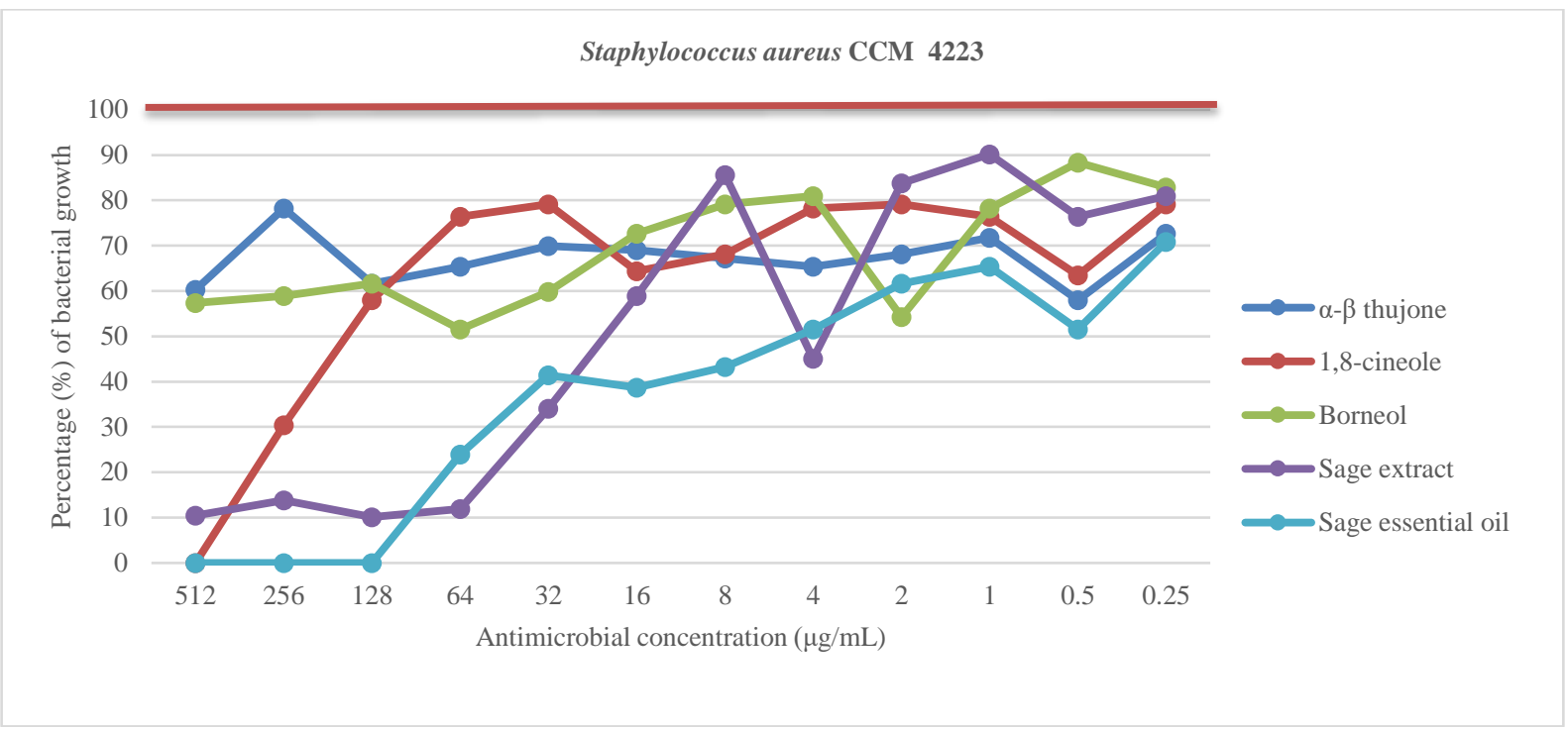

Figure 2 The percentage (\%) growth of S. aureus CCM 4223

The Gram-negative bacteria E. coli CCM 3954 (Fig. 3) was more sensitive to antimicrobial agents such as K. pneumoniae CCM 2318 (Fig. 4). The growth of E. coli was inhibited by sage essential oil at the concentration $256 \mu \mathrm{g} / \mathrm{mL}$, completely. The most effective tested antimicrobial was $\alpha-\beta$ thujone, which was able to inhibit the growth of E. coli below 100\% throughout the cultivation period. The highest increase in its growth was observed at a concentration of 0.5 $\mu \mathrm{g} / \mathrm{mL}(50 \%)$. K. pneumoniae CCM 2318 was the most resistant bacteria from all tested species. The sage extract was able to inhibit its growth up to a concentration of $256 \mu \mathrm{g} / \mathrm{mL}$ completely. Other tested antimicrobials were able to inhibit growth of $K$. pneumoniae completely, only at the initial concentration $(500 \mu \mathrm{g} / \mathrm{mL})$. The best results were observed in the treatment with $\alpha-\beta$ thujone that inhibited growth of this strain below 50\% until the concentration of 16 $\mu \mathrm{g} / \mathrm{mL}$.

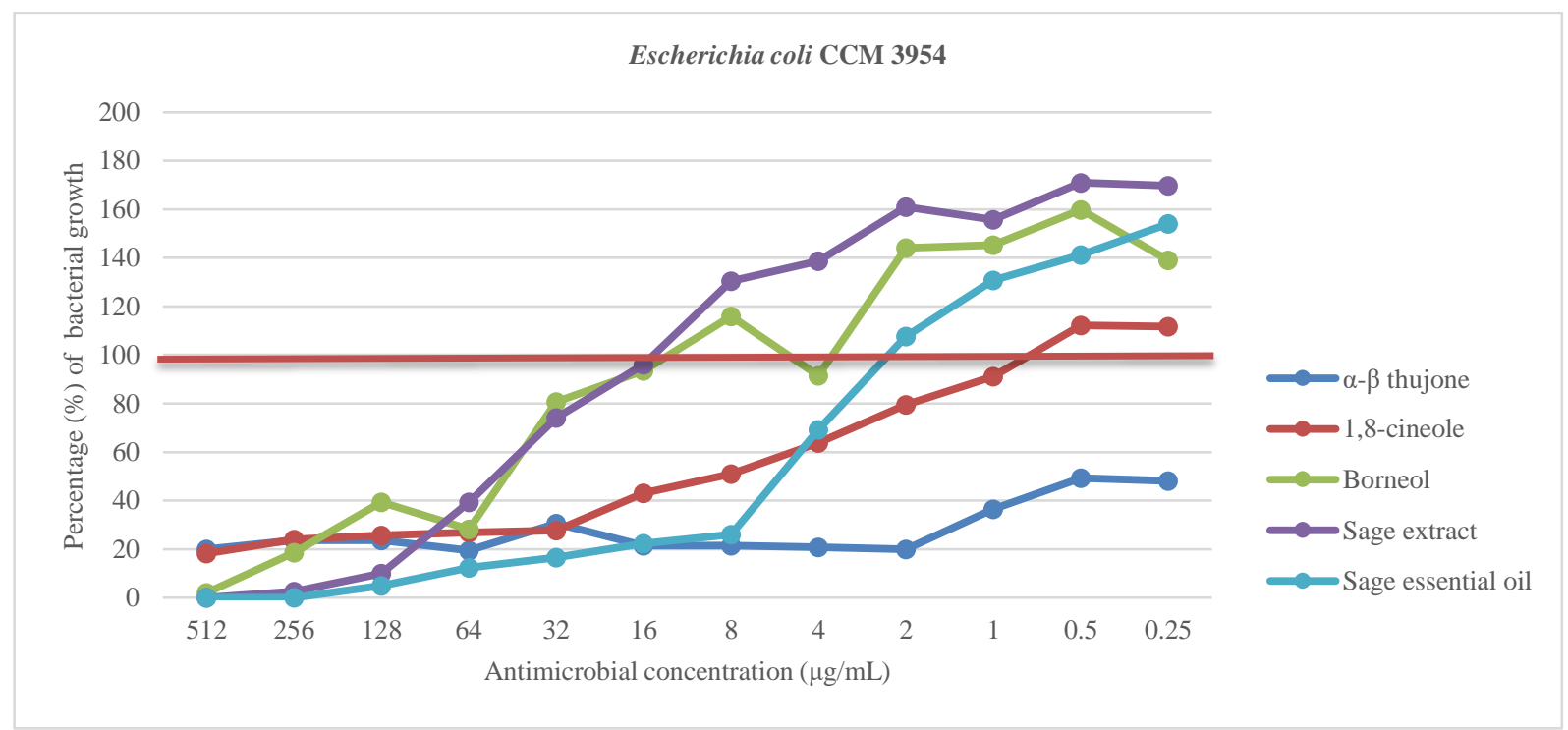

Figure 3 The percentage (\%) growth of E. coli CCM 3954 
Klebsiella pneumoniae CCM 2318

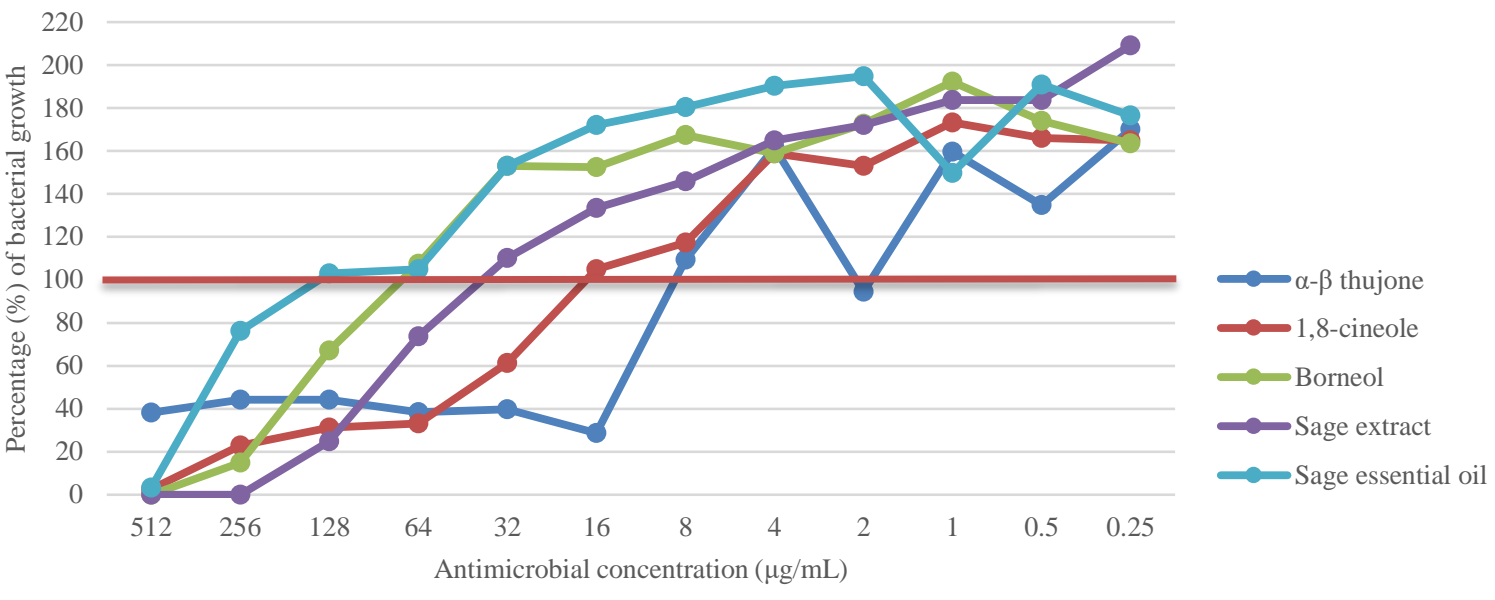

Figure 4 The percentage (\%) growth of K. pneumoniae CCM 2318

Many authors investigated the antibacterial activity of essential oils or some compounds related with the MIC and MBC activities, mainly.

But for a determination of MIC concentration the bacterial growth is usually checked only visually. However, we also focused on monitoring the percentage growth of bacteria treated with antimicrobial agents and we compared the obtained data with the control samples, in this study.

We found some differences between the MIC values and percentage growth of bacteria. For example, the $\alpha-\beta$ thujone had no antimicrobial effect on the growth of tested strains in determination of MIC values. However, when we compared the data obtained from MIC determination and from the percentage growth of bacteria, we found that $\alpha-\beta$ thujone was particularly effective against Gramnegative bacteria. This compound was able to inhibit their growth under $50 \%$ throughout all cultivation time at relatively low concentrations. Based on the results, therefore, it is necessary to obtain more data from the experiments to compare them in assessing the antimicrobial activity.

To identify the various antimicrobial compounds that might be contained in each EO used in the present study, GC/MS analysis was applied. Sage EO contain primarily $\alpha$-thujone (14\%) and the presence of other isoprenoids such as borneol, camphor, (-)-Isopulegol and 1,8-cineole (Table 2). These compounds may contribute to antibacterial effects. Also Russo et al. (2013) studied the chemical composition of different $S$. officinalis essential oils. Their results showed that the main components were $\alpha$-thujone, camphor, borneol, c-Muurolene and sclareol for all the samples. These findings correspond with our results.

Table 2 Qualitative and quantitative analysis (\%) of the sage essential oil by GCMS

\begin{tabular}{|c|c|c|}
\hline $\mathbf{R I}^{\mathbf{b}}$ & Component & Sage $^{c}$ \\
\hline 938 & $\alpha$-pinene ${ }^{\mathrm{a}}$ & 5.40 \\
\hline 953 & Camphene & 5.00 \\
\hline 981 & $\beta$-Pinene ${ }^{a}$ & 1.60 \\
\hline 1034 & 1,8-cineole & 8.00 \\
\hline 1062 & $\gamma$-Terpinene & 1.10 \\
\hline 1107 & $\alpha$-thujone & 14.00 \\
\hline 1116 & ß-thujone & 8.40 \\
\hline 1143 & camphor & 12.90 \\
\hline 1148 & (-)-Isopulegol & 10.10 \\
\hline 1168 & borneol $^{\mathrm{a}}$ & 12.90 \\
\hline 1287 & (-)-Bornyl acetate & 5.20 \\
\hline 1419 & $\beta$-Caryophyllene & 1.60 \\
\hline 1436 & $\gamma$-Elemene & 3.40 \\
\hline 1478 & $\gamma$-Muurolene & 5.40 \\
\hline 1574 & Caryophyllene oxide & 1.20 \\
\hline \multicolumn{2}{|r|}{ total } & 96.20 \\
\hline
\end{tabular}

Legend: ${ }^{a}$ - Identification confirmed by co-injection of authentic standard; ${ }^{b}$ - R identification based on Kovat's retention indices (HP-5MS capillary column) and mas spectra; ${ }^{c}$ - relative proportion was calculated in $\%$ by dividing individual peaks area by total area of all peaks.

The sage EO and extract were subjected to screening for their possible antioxidant activity. Free radical scavenging capacities of the antimicrobials, measured by DPPH assay, are shown in Table 3. As the best scavenging solutions of DPPH radical were the oils at the highest concentration $50 \mu \mathrm{g} / \mathrm{mL}$, with the decreasing concentration of oil solution, the antioxidant activity was reduced (not shown). DPPH radical-scavening activities of 15 EOs were studied in the work of Kačániová et al. (2014). They observed the highest \% of inhibition at Origanum vulgare (93\%), Satureia montana $(90.66 \%)$ and Lavandula augustifolia $(90.22 \%)$. For Salvia officinalis was found a lower antioxidant activity $(68.55 \%)$.
Our results showed higher antioxidant activity of sage EO $(71.55 \%)$, but the sage propylene glycol extract showed the lowest antioxidant activity (60.93\%). The better antioxidant activity of sage extracts was observed by Süntar et al. (2011) at Salvia cryptantha $(85.47 \%)$ but at the highest concentration of $500 \mu \mathrm{g} / \mathrm{mL}$.

Table 3 Antioxidant activity expressed as \% inhibition of DPPH radical at 50 $\mu \mathrm{g} / \mathrm{mL}$ concentration of tested antimicrobials

\begin{tabular}{l|c}
\hline Antimicrobials & Antioxidant activity (\%) \\
\hline Sage essential oil & 71.55 \\
Sage propylene glycol extract & 60.93 \\
\hline \multicolumn{2}{c|}{ Legend: The values represent the average (standard deviations) for triplicate analyses }
\end{tabular}

\section{CONCLUSION}

Salvia officinalis L. is a promising source of essential oil or extracts. According to the results of this study, it can be concluded that sage EO, and antimicrobials such as $\alpha-\beta$ thujone, 1,8 -cineole and borneol showed promising antimicrobial effects. The best minimum inhibitory concentration (MIC) was found against Gram-positive bacteria $S$. aureus CCM 4223 by sage essential oil with MIC $_{50}$ $96.05 \mu \mathrm{g} / \mathrm{mL}$. That allows it to be used by the pharmaceutical and cosmetic industries as natural preservative. However, we also studied the percentage growth of bacteria treated with antimicrobial agents. Subsequently we compared the obtained data with the control samples and found some differences between the MIC values and percentage growth of bacteria. We found that $\alpha-\beta$ thujone had no antimicrobial effect in determination of MIC values, but it was particularly effective against Gram-negative bacteria in percentage (\%) growth study. Therefore, there is necessary to obtain more data from the experiments to compare them in assessing the antimicrobial activity. Chromatographic analysis demonstrated that sage oil is rich in bioactive compounds, such as $\alpha$-thujone, borneol, camphor, (-)-Isopulegol or 1,8-cineole. Our results showed higher antioxidant activity of sage EO $(71.55 \%)$ and the less antioxidant activity for a sage extract $(60.93 \%)$. Due to antibacterial activity of the tested antimicrobials from sage, the problem of microbial resistance to conventional antibiotics could be treated by pharmaceutical industries to manufacture antibacterial drugs.

Acknowledgements: This work was supported by project no. FPPV-09-2019 and by Slovak Research and Development Agency under Contract no. APVV-160173 .

\section{REFERENCES}

ADAMS RP. 2007. Identification of essential oil components by gas chromatography/ mass spectrometry. $4^{\text {th }}$ ed. Carol Stream, IL: Allured Publishing Corporation; 2007.

BARRETO, H. M., SILVA FILHO, E. C., LIMA, E. D. O., COUTINHO, H. D., MORAIS-BRAGA, M. F., TAVARES, C. C., SAULO R.TINTINO, JUCIANE V. REGO, AISLAN P.L. DE ABREU, MARIA DO CARMO GOMES LUSTOSA, GUIMARÃES OLIVEIRA, R. W., ANTONIA M.G.L. CITÓ, DANTAS LOPES, J. A. 2014. Chemical composition and possible use as adjuvant of the antibiotic therapy of the essential oil of Rosmarinus officinalis $\mathrm{L}$. $\begin{array}{llll}\text { Industrial Crops and Products, 290-294. } & \end{array}$ https://doi.org/10.1016/j.indcrop.2014.05.026

BOSNIĆ, T., SOFTIĆ, D., \& GRUJIĆ-VASIĆ, J. 2006. Antimicrobial activity of some essential oils and major constituents of essential oils. Acta Medica Academica, 35(1), 9-14. 
CÍSAROVÁ, M., HLEBA, L., TANČINOVÁ, D., FLORKOVÁ, M. FOLTINOVÁ, D., CHAROUSOVÁ, I., \& KLOUČEK, P. 2018. Inhibitory effect of essential oils from some Lamiaceae species on growth of Eurotium spp. isolated from bread. Journal of Microbiology, Biotechnology \& Food Sciences, 8(2). https://doi.org/10.15414/jmbfs.2018.8.2.857-862

CLINICAL AND LABORATORY STANDARDS INSTITUTE (CLSI). 2009. Methods for dilution antimicrobial susceptibility tests for bacteria that grow aerobically, approved standard. 8th ed. Wayne, PA: CLSI; 2009 [CLSI document M7-A8].

HATANO T., KAGAWA H., YASUHARA T. \& OKUDA T. 1988. Two new flavonoids and other constituents in licorice root: their relative astringency and radical scavenging effects.Chem. Pharm. Bull. 36, 2090-2097. https://doi.org/10.1248/cpb.36.2090

HLEBA, L., VUKOVIĆ, N., HORSKÁ, E., PETROVÁ, J., SUKDOLAK, S. KACÁAIOVÁ, M. 2014. Phenolic profile and antimicrobial activities to selected microorganisms of some wild medical plant from Slovakia. Asian Pacific Journal of Tropical Disease,4(4), 269-274. https://doi.org/10.1016/s22221808(14)60571-5

HSOUNA, A.B., TRIGUI, M., MANSOUR, R.B., JARRAYA, R.M., DAMAK, M., JAOUA, S. 2011. Chemical composition, cytotoxicity effect and antimicrobial activity of Ceratonia siliqua essential oil with preservative effects against Listeria inoculated in minced beef meat, International Journal of Food Microbiolology,

(1),

$66-72$.

https://doi.org/10.1016/j.ijfoodmicro.2011.04.028

JENKINS, D. R. 2017. Nosocomial infections and infection control. Medicine, 45(10), 629-633. https://doi.org/10.1016/j.mpmed.2017.07.005

KAČÁNIOVÁ, M., VUKOVIČ, N., HORSKÁ, E., ŠALAMON, I., BOBKOVÁ, A., HLEBA, L., \& BOBKO, M. 2014. Antibacterial activity against Clostridium genus and antiradical activity of the essential oils from different origin. Journal of Environmental Science and Health, Part B, 49(7), 505-512. https://doi.org/10.1080/03601234.2014.896673

LAHMAR, A., BEDOUI, A., MOKDAD-BZEOUICH, I., DHAOUIFI, Z KALBOUSSI, Z., CHERAIF, I., GHEDIRA, K., CHEKIR-GHEDIRA, L. 2017. Reversal of resistance in bacteria underlies synergistic effect of essential oils with conventional antibiotics. Microbial pathogenesis, 106, 50-59. https://doi.org/10.1016/j.micpath.2016.10.018

MANDRAS, N., NOSTRO, A., ROANA, J., SCALAS, D., BANCHE, G., GHISETTI, V., et al., 2016. Liquid and vapourphase antifungal activities of essential oils against Candida albicans and non-albicans Candida. BMC Complement. Altern. Med. 16(1), 330. https://doi.org/10.1186/s12906-016-13165

MARTINS, N., BARROS, L., SANTOS-BUELGA, C., HENRIQUES, M., SILVA, S., \& FERREIRA, I. C. 2015. Evaluation of bioactive properties an phenolic compounds in different extracts prepared from Salvia officinalis L. Food chemistry, 170, 378-385. https://doi.org/10.1016/j.foodchem.2014.08.096

O'NEILL, J. 2014. Antimicrobial resistance: tackling a crisis for the health and wealth of nations. Review on Antimicrobial Resistance, 20, 1-16.

RAGHEB, M. N., THOMASON, M. K., HSU, C., NUGENT, P., GAGE, J., SAMADPOUR, A. N., KARIISA, A., MERRIKH, CH. N., MILLER, S. I., SHERMAN, D. R., MERRIKH, H. 2018. Inhibiting the Evolution of Antibiotic Resistance. Molecular Cell, $\quad 73, \quad 1-9$ https://doi.org/10.1016/j.molcel.2018.10.015

RASHID, S., RATHER, M. A., SHAH, W. A., \& BHAT, B. A. 2013. Chemical composition, antimicrobial, cytotoxic and antioxidant activities of the essentia oil of Artemisia indica Willd. Food chemistry, 138(1), 693-700. https://doi.org/10.1016/j.foodchem.2012.10.102

RAUT, J. S., KARUPPAYIL S. M. 2014. A status review on the medicinal properties of essential oils. Industrial Crops and Products, 62, 250-264. https://doi.org/10.1016/j.indcrop.2014.05.055

ROBY, M. H. H., SARHAN, M. A., SELIM, K. A. H. \& KHALEL, K. I. 2013. Evaluation of antioxidant activity, total phenols and phenolic compounds in thyme (Thymus vulgaris L.), sage (Salvia officinalis L.), and marjoram (Origanum majorana L.) extracts. Industrial Crops and Products, 43, 827-831. https://doi.org/10.1016/j.indcrop.2012.08.029

RUSSO, A., FORMISANO, C., RIGANO, D., SENATORE, F., DELFINE, S., CARDILE, V. \& BRUNO, M. 2013. Chemical composition and anticancer activity of essential oils of Mediterranean sage (Salvia officinalis L.) grown in different environmental conditions. Food and Chemical Toxicology, 55, 42-47. http://dx.doi.org/10.1016/j.fct.2012.12.036

SHAHBAZI, Y. 2015. Chemical composition and in vitro antibacterial activity of Mentha spicata essential oil against common food-borne pathogenic bacteria. Journal of Pathogens. 2015, 916305. http://dx.doi.org/10.1155/2015/916305

SNOUSSI, M., NOUMI, E., TRABELSI, N., FLAMINI, G., PAPETTI, A., DE FEO, V. 2015. Mentha spicata essential oil: chemical composition, antioxidant and antibacterial activities against planktonic and biofilm cultures of Vibrio spp. $\begin{array}{llll}\text { strains. } & \text { Molecules, } & \text { 20, }\end{array}$ https://doi.org/10.3390/molecules200814402

SÜNTAR, İ., AKKOL, E. K., SENOL, F. S., KELES, H., \& ORHAN, I. E. 2011. Investigating wound healing, tyrosinase inhibitory and antioxidant activities of the ethanol extracts of Salvia cryptantha and Salvia cyanescens using in vivo and in vitro experimental models. Journal of ethnopharmacology, 135(1), 71-77. https://doi.org/10.1016/j.jep.2011.02.022

TACCONELLI, E., CARRARA, E., SAVOLDI, A., HARBARTH, S., MENDELSON, M., MONNET, D. L., \& OUELLETTE, M. 2018. Discovery, research, and development of new antibiotics: the WHO priority list of antibioticresistant bacteria and tuberculosis. The Lancet Infectious Diseases, 18 (3), 318 327. https://doi.org/10.1016/S1473-3099(17)30753-3

TSIRI, D., GRAIKOU, K., POBŁOCKA-OLECH, L., KRAUZEBARANOWSKA, M., SPYROPOULOS, C., \& CHINOU, I. 2009. Chemosystematic value of the essential oil composition of Thuja species cultivated in Poland-antimicrobial activity. Molecules, 14(11), 4707-4715. https://doi.org/10.3390/molecules 14114707

VERAS, H. N. H., RODRIGUES, F. F. G., COLARES, A. V., MENEZES, I. R A., COUTINHO, H. D. M., BOTELHO, M. A., COSTA, J.G. 2012. Synergistic antibiotic activity of volatile compounds from the essential oil of Lippia sidoides and thymol. Fitoterapia, 83, 508-512. https://doi.org/10.1016/j.fitote.2011.12.024 VETAS, D., DIMITROPOULOU, E., MITROPOULOU, G., KOURKOUTAS, Y., \& GIAOURIS, E. 2017. Disinfection efficiencies of sage and spearmint essential oils against planktonic and biofilm Staphylococcus aureus cells in comparison with sodium hypochlorite. International journal of food microbiology, 257, 19-25. https://doi.org/10.1016/j.ijfoodmicro.2017.06.003

VILJOEN, A. M., VAN VUUREN, S. F., GWEBU, T., DEMIRCI, B., \& BAŞER, K. H. C. 2006. The Geographical Variation and Antimicrobial Activity of African Wormwood (Artemisia afra Jacq.) Essential Oil. Journal of Essential Oil Research, 18, 19-25.

VOSOUGHI, N., GOMARIAN, M., PIRBALOUTI, A. G., KHAGHANI, S., \& MALEKPOOR, F. 2018. Essential oil composition and total phenolic, flavonoid contents, and antioxidant activity of sage (Salvia officinalis L.) extract under chitosan application and irrigation frequencies. Industrial Crops and Products, 117, 366-374. https://doi.org/10.1016/j.indcrop.2018.03.021

WORLD HEALTH ORGANIZATION. 2017. Global priority list of antibioticresistant bacteria to guide research, discovery, and development of new antibiotics. Geneva: World Health Organization. 6-7. 